Article

\title{
The Living Goddess of Mercy at the Rape of Nanking: Minnie Vautrin and the Ginling Refugee Camp in World War II (1937-1938) ${ }^{\dagger}$
}

\section{Sheng-Ping Guo}

Emmanuel College, University of Toronto, 75 Queen's Park Crescent East, Toronto, ON, M5S 1K7, Canada; shengping.guo@mail.utoronto.ca; Tel.: +1-416-659-6799

+ I thank one of the anonymous reviewers who raised the issue of how to deal with the Nanking Atrocity time period of 1937 to 1938: whether this period should be interpreted as connected to the Second Sino-Japanese War (1937-1945) or as part of the Second World War. In this paper, I hav adopted the second viewpoint to point to the wide global impact of these events and provide a sufficient background for my argument. I also thank another anonymous expert who carefully reviewed the paper and raised a question about the standard system of Romanization. Throughout this paper, generally, I used the Pinyin, while in a few situations I have chosen to use Wade-Giles to provide a sense of historical narratives and to maintain the material's originality, for example, in cases of Nanking, Ginling, and a few Chinese family names. Other Wade-Giles nouns have been used in this paper simply because I could not work out accurate Pinyin based upon the historical documents.

Academic Editor: Mark G. Toulouse

Received: 20 September 2016; Accepted: 5 December 2016; Published: 17 December 2016

\begin{abstract}
During the infamous Nanking Atrocity, some Western businesspersons and missionaries established the Nanking Safety Zone to protect about 250,000 refugees. When the Japanese army was pressing on Nanking, Minnie Vautrin, an educational missionary from the United Christian Missionary Society, took charge of the Ginling College campus. As one of the 25 refugee camps, Ginling provided shelter to about 10,000 women and children in late December 1937-the hardest time during World War II in China. With her neutral identity of American nationality, Vautrin seriously struggled with Japanese soldiers when they were seizing Chinese women for rape from the campus; thus, she helped many women avoid the possible fate of sexual violence and slaughter. The Chinese people promoted her as a "Goddess of Mercy", in the Chinese language a "Living Buddha" (Huo pu sa) or "Guanyin Buddha" (Guan Yin pu sa). The Chinese central government awarded her the Order of Jade (Cai Yu xun zhang). Drawing from Vautrin's diaries and other original materials, this paper narrates this Christian female missionary's moving story in humanism, evangelism, and internationalism. Her devotion to the Chinese refugee women and children made her an eyewitness to the Nanking Massacre, a rehabilitator of refugee sufferings, and a mental and bodily victim of disastrous war.
\end{abstract}

Keywords: Nanking Massacre; Minnie Vautrin; humanism; evangelism; internationalism; World War II

\section{Introduction}

On 15 May 1941, Mr. C. M. Yocum, the executive secretary of the United Christian Missionary Society, an organization affiliated with the Disciples of Christ, issued a letter to "Dear Friends of Minnie Vautrin". The letter announced her unexpected death on 14 May and noted that "We feel that Miss Vautrin was truly a causality of the war as any soldier who [has] fallen on the battlefield" ([1], p. 144) ${ }^{1}$.

1 C. M. Yocum, “Dear Friends of Minnie Vautrin”. 15 May 1941, Correspondence, Minnie Vautrin, Disciples of Christ Historical Society Library, Nashville, Tennessee (cited in [1]). 
Vautrin was buried beside the tomb of her parents at the Salt River Cemetery in Shepherd, MI, USA. Four Chinese characters and five-line English words on her tombstone are as follows:

\author{
金永 \\ 陵生 \\ MINNIE VAUTRIN \\ "GODDESS OF MERCY" \\ MISSIONARY TO CHINA \\ 28 YEARS \\ 1886-1941
}

The phrase of the four Chinese characters "Gin Ling Yong Sheng" means "Eternally Live[ing] in the Heart of Ginling" [2] ${ }^{2}$. Shortly before her death, Vautrin once told her friends that if she could live twice, she would still want to serve the Chinese people because China was her "home" ([1], p. 144) ${ }^{3}$.

Minnie Vautrin devoted her prime years to China and Chinese women. Born in Secor, IL, USA on 27 September 1886, to a farming family, she eventually majored in education at the University of Illinois. The Foreign Christian Missionary Society, a predecessor body of the United Christian Missionary Society ${ }^{4}$, commissioned her as a missionary to China in 1912. She served for several years as principal of the girl's middle school in Hefei, the first of its kind in the Luzhou Prefect of Anhui province when most Chinese women were illiterate and did not get an education. Later, she became dean and professor of the education department at the Ginling College in Nanking in 1919. When the Japanese army marched on Nanking, then the capital city of the Republic of China, she took charge of the College campus as most of the faculty left Nanking for Shanghai and Chengdu, including President Wu Yi-fang who left on 1 December 1937 ([2], 1 December 1937). During the infamous Nanking Atrocity, Vautrin opened the Ginling campus as a refugee camp and accepted about 10,000 civilian women and children during its peak time-late December $1937[3]^{5}$. She helped women avoid the possible fate of being killed or raped by Japanese soldiers. On July 30, 1938, the government of the Republic of China promoted her devotion to the protection of refugees and secretly awarded her the Order of Jade (Cai Yu xun zhang)—-the highest honor bestowed to foreigners ([1], p. 124). The Chinese people called her the "Goddess of Mercy", and described her in the Chinese language as a "Living Buddha" (Huo pu sa) or "Guanyin Buddha" (Guan Yin pu sa).

During the first six weeks of occupation, the Japanese troops murdered more than 200,000 Chinese civilians and prisoners of war in the city and its vicinity ([4], p. 49,608; [5], p. x; [6], p. 6) ${ }^{6}$, raped approximately 20,000 Chinese women from age 9 to 76 in the city ([2], 15 March 1937; [4],

2 In this paper, when I cite the Diary of Wilhelmina [Minnie] Vautrin, 1937-1940, I used the Diary date after the reference number [2]. See this citation on the last page (no page number) of the Diary, "Minnie Vautrin", condensed from notes provided by Dr. Treudley and Mrs. New, December 1968.

3 Hua-ling Hu's interview with Ms. Emma Lyon, Vautrin's niece, at Shepherd, MI, USA, 25-26 May 1995 (cited in [1]).

4 I thank one of the anonymous reviewers for his or her expertise on this point.

5 See the letter Minnie Vautrin sent to "Dear Mrs. Thurston, Yi-fang, Ruth and Rebecca" on 6 January 1938. It states that "About December 17th, when we had our peak load, we think we must have had at least 9000 or 10,000 people", in Anna E. Moffet Jarvis, Correspondence, China Records Project Miscellaneous Personal Papers Collection, Record Group 8, Box 103, Special Collections, Yale University Divinity School Library. Also a diplomatic telegram John M. Alison, third secretary of the American Embassy in Nanking who dispatched on Minnie Vautrin's behalf to Priest Abchicol (also named Rebecca Walter Griest) on 6 January 1938, states that "Are now sheltering approximately 10,000 women and children", in Record Group 59, Box 1795, the National Archives II, College Park, MD. I cited from the source [3] on page 109 and page 111 .

6 The International Military Tribunal for Far East (IMTFE) (Tokyo War Crimes Trial) estimated and judged this number of people had been murdered during the first six-week period. On page 6 of reference [6], Joshua A. Fogel admitted that there was an argument about the numbers, but he and the other contributors of that volume, Mark Eykholt, Charles Maier, Daqing Yang, and Takashi Yoshida, "are all of a mind that a great massacre occurred, and whether 200,000 people were killed or 240,000 does not alter the dimensions of the horror." 
pp. 49, 605-6; [5], p. x $)^{7}$, looted all properties they had seen and wanted, and burned one-third of the city to ash ([7], p. 6). The infamous Nanking Massacre made the former prosperous capital "a hell on earth" and a "dead city" of terror with "no parallel in modern history" ([8], p. 83) ${ }^{8}$. From 22 November 1937 to 21 May 1938, some Western businesspersons and Christian missionaries operated the International Committee for the Nanking Safety Zone (ICNSZ) to provide shelter for very nearly 250,000 Chinese refugees in 25 camps [9] $]^{9}$. Vautrin was one of the core members of the International Red Cross Committee in Nanking, which worked closely together with ICNSZ and other wartime relief organizations, including the University of Nanking Hospital, refugee camps, and the local Christian churches and institutions. She was also one of the thirteen American missionaries who remained after the fall of Nanking to provide protection for Chinese civilians ([8], pp. xviii-xxvii; [9]; [10], pp. 11-18) ${ }^{10}$.

This study focuses on the mission service of Minnie Vautrin during the Nanking Massacre and refugee camp period from 22 November 1937, to 21 May 1938. As an educational missionary, Vautrin played a key role in the emerging crisis. The horrendous methods of modern war with aerial bombing and fierce atrocity in contested urban spaces created within her an awareness of the need to provide safety and shelter to woman and child victims. Under Vautrin's leadership, the Ginling campus, well beyond its capacity, accepted refugee women and children during their hardest time. In the course of her work, Vautrin displayed an unusual ability to organize available sources and mobilize official support to deal with the unprecedented catastrophes associated with the occupation of Nanking. She provided a small harbor to protect the endangered Chinese refugee women and children. With her neutral American identity, Vautrin seriously struggled with Japanese soldiers who attempted to seize Chinese women from the Ginling campus to rape. Drawing from Vautrin's diaries and other first-hand materials, in the next parts of this paper, I will narrate this Christian female missionary's moving story. Her devotion to the Chinese refugee women and children made her an eyewitness to the Nanking Massacre, a rehabilitator of refugee sufferings, and a mental and bodily victim of disastrous war.

7 According to the judgment of the International Military Tribunal for Far East, "Approximately 20,000 cases of rape occurred within the city during the first month of the occupation."

8 George Ashmore Fitch. "Diary." In Archives of the United Board for Christian Higher Education in Asia, Record Group No. 11, Box 9, File 202, Special Collections, Yale University Divinity School Library (cited in [8]).

9 "Report of the Nanking International Relief Committee (November 1937-30 April 1938)." In the Miner Searle Bates Paper, Record Group No. 10, Box 102, Folder 868: Nanking during Sino-Japanese conflict April-Nov. 1938. I cited from the Nanking Massacre Archival Project, NMP 0248, by the Yale University Divinity School Library. On 19 February 1938, the International Committee for Nanking Safety Zone changed its name to the Nanking International Relief Committee, in order to concentrate on relief work in the city.

10 The thirteen American missionaries were: Dr. Miner Searle Bates (University of Nanking, Administrator and Professor), Ms. Grace Louis Bauer (University Hospital, Lab Technician), Rev. George A. Fitch (Nanking YMCA, Secretary), Rev. Ernest H. Forster (American Church Mission, Clergyman), Rev. John Magee (American Church Mission, Clergyman), Rev. James McCallum (United Christian Missionary Society, Clergyman who worked for the University Hospital), Rev. Wilson Plumer Mills (Northern Presbyterian Mission, Clergyman), Mr. Charles H. Riggs (University of Nanking, Professor), Dr. Lewis S. C. Smythe (University of Nanking, Professor), Dr. Rev. Hubert Sone (Nanking Theological Seminary, Professor), Dr. Clifford S. Trimmer (University Hospital, Doctor), Ms. Minnie Vautrin (Ginling College, Administer and Professor), and Dr. Robert Ory Wilson (University Hospital, Doctor). I compiled this list with data and cross-referenced with research from the references. This list does not include Mrs. Paul de Witt Twinem (Mary D. Fine) as she had given up American citizenship for a Chinese one, but she functioned as a foreign missionary during the Rape of Nanking. This list also excludes Ms. Iva Hynds, an American nurse at the University Hospital, because I did not find records to indicate her direct connection with any mission. Considering the University Hospital was a missionary institute and her close work relationships, Ms. Hynds probably could be counted as a medical missionary. Four other Americans remaining at the time of the fall of Nanking were Frank Tillman Durdin (The New York Times, Journalist), Charles Yates McDaniel (Associated Press, Journalist), Arthur von Briesen Menken (Paramount Newsreels, Journalist), and Archibald Trojan Steele (Chicago Diary News, Journalist). A total of eighteen Americans stayed. 


\section{Discussion}

\subsection{Ginling Campus}

Before President Wu Yi-fang departed from the Ginling College, she had appointed an Emergency Committee to carry on the responsibility of management through the crisis time, consisting of Ms. Minnie Vautrin, Mrs. Shui-fang Tsen, and Mr. Francis Chen. The Committee members and other staff worked at top speed to put up American flags and Japanese proclamations, burn papers and hide valuables, and prepared spaces for refugees. They emptied eight buildings in good condition and planned a capacity of 2750 for the refugee camp ([2], 7 December 1937). On 8 December, they began to receive the first group of refugee women and children. Three-hundred people who arrived on the night of 9 December had previously evacuated from the battlefront in Shanghai, Wuxi, Suzhou, and from other places where the Japanese armies were advancing to conquer ([2], 9 December 1937). Some of them had been residents near the city wall of Nanking but had abandoned their homes under the Chinese military order. By Saturday, 11 December, a total of 850 refugees were accepted and set down in the Central Building and one of the dormitories ([2], 11 December 1937). Because most of the early groups of refugees had brought their food with them, the camp had plenty of food in the early days.

The Japanese army seized and occupied the whole city by four o'clock on the morning of 13 December. For the next few days, as conditions for Chinese civilians grew worse, refugee women streamed in from daylight on. By Thursday, 16 December, the Ginling campus contained more than 4000 people [11]. However, from camp refugees, Vautrin and staff immediately realized the unprecedented danger facing women who remained in their own homes. Japanese soldiers searched for any females. From ages under ten to over seventy, women were unlikely to remain "free from mistreatment" [11]. As the protector of the Ginling property, Vautrin finally decided she should use her strength "to save lives and not try to save things" [11]. To her, it would be better "to face the future with marred and soiled walls than not to have done this humanitarian service for the women and children who have come to us. We could not have closed our doors against them" [12]. On 17 December, Vautrin took about 1000 women over to the neighboring University of Nanking refugee camp, while she kept the Ginling camp gate open [11].

Vautrin and her colleagues let the woman and child refugees come in because all of them "were content to sleep outside" [11]. On 17 December, more than 4000 additional refugees arrived and crammed like sardines in the buildings and stairs, halls, covered ways, and verandas ([2], 17 December 1937). By 22 December, the number of refugees reached 10,000 ([2], 22 December 1937). The situation outside camps was desperate as Vautrin described the situation: "how many thousands were mown down by guns or bayoneted we shall probably never know for in many cases oil was thrown over their bodies and they were burned-charred bones tell the tale of some of these tragedies" [11]. In her report, she expressed her sympathy to those poor and desperate women and children:

Never shall I forget the faces of the young girls as they streamed in-most of them parting from their fathers or husbands at the gate. They had disguised themselves in every possible way-many had cut their hair, most of them had blackened their faces, many were wearing men or boy's clothes or those of old women. Mr. Wang, Mr. Hsia, Mary and I spent our days at the gate trying to keep idlers out and let the women come in. At our peak load[,] we must have had ten thousand on the campus...I shall never forget the faces of the fathers and husbands as they watched their women folk enter the campus. Often times the tears were streaming down their cheeks as they begged us to "just give them a place to sleep outside" [11].

In addition to providing shelter, the more complicated tasks included feeding the multitude and maintaining the sanitary health of the public. Fortunately, on the day the Japanese conquered the city, the International Red Cross Committee in Nanking started a rice kitchen just north of the Ginling 
campus. The well-managed kitchen provided two meals of soft rice or rice each day to the refugees. If the women and girls could afford it, they would pay three copper for a bowl of hot rice; if not, the camp staff would investigate the case and give each of them a red tag entitling them to free rice [11]. To provide for hot water, Vautrin put two men in charge. They moved a big water-stove on campus, so women in Ginling had hot water during the day. Vautrin and her team also slowly worked out solutions to deal with the sanitary issues as lime were used in necessary places and along two deep trenches - one on the hill at the back of the Central Building and another on a hill at the back of the Arts Building. These trenches were dug to bury the night soil disposal ([3], p. 181) $)^{11}$. For laundry, women washed clothes by hand and hung them on bushes, trees, and fences during most of the day.

Japanese troops continuously disturbed the Ginling campus, seeking women to rape and Chinese soldiers to slaughter. During the ten days from 13 to 23 December, every day, ten to twenty groups of Japanese soldiers broke into the campus. Most of them broke through an open side, back gates, or jumped over fences, while only a few charged the front gate. According to Vautrin, "Some soldiers were fierce and unreasonable and most of them had their bayonets out ready for use and on not a few of them[,] I could see fresh blood stains" [11]. Because "the presence of a foreigner was of great help" when a soldier group came on campus, the staff of servants would always run to Vautrin [11]. She thus had to spend her days "in running from the gate to the south hill or the back hill or to the poultry experiment or to one of the dormitories" to escort the Japanese soldier groups "out of a dormitory filled with refugee women and children or from the south hill residence" [11]. In order to show a foreign face for security reasons, Vautrin always made sure that she and Ms. Mary D. Fine (well known as Mrs. Paul de Witt Twinem) would never leave the campus at the same time. One of them would permanently hold the letter from the Japanese Embassy in order to safeguard all people in buildings.

\subsection{Witness to the Nanking Massacre}

The Japanese employed a brutal "Three Alls" policy: Kill All, Loot All, and Burn All. They raped women and killed families, pillaged belongings, and burned houses. The atrocities made everyone terrified. The special responsibility accompanying the constant protection of Ginling camp refugees provided Minnie Vautrin with few opportunities to visit the whole city. However, she witnessed firsthand, and recorded, many miserable scenes associated with the Nanking Massacre. In dealing with woman and refugee children, she experienced her own forms of serious depression and deep physical hurt that she never resolved in her life.

\subsubsection{Mass Slaughter}

Vautrin witnessed Japanese soldiers killing Chinese soldiers hiding in the Nanking Safety Zone. On 16 December, she noted that, had the Japanese troops "found any suspected person, his fate would have been the same as that of four men" whom the Japanese had roped together-"They took them to our west hill, and there I heard the shots" ([2], 16 December 1937). Later, on 31 January, she dared to venture out of the campus. Up the west hill, she came across the bodies of the men "whom I heard shot" "and who looked to me like civilians" ([2], 31 January 1938). On December 14, she saw a group of one hundred or more civilians with bound hands walking behind the Japanese soldiers and cavalry and passing the Ginling gate; they were treated as Chinese soldiers and were slaughtered ([2], 8 February 1938). On 21 December at 1:30 p.m., by way of an American Embassy car, she traveled west with Mr. George Atcheson's cook who was anxious to see if his 75-year-old father had been killed as he had heard. Vautrin wrote:

We found the old man lying in [the] middle of the road...The old man had refused to go to the Embassy for protection, saying he was sure nothing would harm him...Those of you

11 Letter from Minnie Vautrin to Mrs. Thurston on 9 March 1938. Record Group 11, Box 145, Folder 2875, Special Collections, Yale University Divinity School Library (cited in [3]). 
who have lived in Nanking can never imagine how the streets look like- - the saddest sight I ever hope to see. Buses and cars upset in street, dead bodies here and there, with faces already black, discarded soldiers' clothing everywhere, every house and shop looted and smashed if not burned. In the Safety Zone the streets are crowded-outside you seldom see anyone but Japanese ([2], 21 December 1937).

Vautrin also made historical records whenever she heard of mass slaughter cases. In the afternoon of 22 December, Minister Ernest Herman Forster of the American Church Mission came to Ginling and told Vautrin a sad story. The Japanese Embassy wanted the Xia Guan electricity plant repaired in order to turn on the lights. Mr. John Rabe, then the German business manager of Siemens Company and Chairman of the International Committee for the Nanking Safety Zone, got fifty electricity workers together and took them down to the plant. On the same afternoon, the Japanese soldiers shot forty-three of them saying that they were employees of the government, but actually, they were not ([2], 22 December 1937).

On 23 December, Mr. Swen, a Ginling neighbor living on Hu Ju Guan Street, told Vautrin another mass killing story. "Last night from sixty to a hundred men, mostly young, were taken in trucks to the little valley south of Ginling Temple, shot by machine gun fire, later put into a house and the whole set on fire" ([2], 23 December 1937). Vautrin mentioned in her diary that "I have been suspecting that many of the fires we see at night are to cover either looting or killing" ([2], 23 December 1937). She proved her suspicion later. On 26 January, having worked until almost 5 p.m., she decided to be bold and she took a walk to Hu Ju Guan Street west of Ginling. A woman she knew and her husband led her and her servant to the pond in the Yang valley:

At its edge[,] there were scores of black charred bodies and among them two empty kerosene or gasoline cans. The hands of the men were wired behind them. How many bodies there were, and whether or not they were machine[-]gunned first, and then burned, I do not know, but I hope so. In a smaller pond to the west were perhaps 20-40 more charred bodies. The shoes I saw on several men looked like civilian shoes[,] not soldiers. All through the hills are unburied bodies ([2], 26 January 1938).

At 11 a.m. on 25 March, a man asked Vautrin to guide him to the valley where the dreadful tragedy of 26 December occurred. Some neighboring residents agreed to go with them. "At the edge of the large pond 96 men had suffered a most terrible death, at the other perhaps 43 and about 4 in the farmhouse nearby" ([2], 25 March 1938). The neighbor farmers had collected enough evidence to prove that the Japanese had poured kerosene and gasoline on the bodies first and then ignited the fire. The soldiers aimed machine guns to mow down those men who ran away, and four set on fire ran to the house in their agony and had been burned with the house. Vautrin wrote, "As we stood by the smaller pond we saw what looked to be the top of a head. By means of bamboo poles and a wooden hook the body of the man was slowly pushed to the bank. His clothes were those of civilian. The agony these men must have endured" ([2], 25 March 1938).

During the morning of 15 February, Vautrin received a report that the Swastika Society estimated around 30,000 were killed around Xia Guan, and during that afternoon, she heard another report that "tens of thousands" were slaughtered at Yan Zi Ji-Swallow Cliff where there existed no way to transport the victims across the river ([2], 15 February 1938). Between 5 p.m. and 6 p.m. on 16 February, Mr. Y. G. Yan visited Vautrin. He said he had heard that, during the early days of occupation, 10,000 had been killed at San Cha He, 20,000 to 30,000 at Yan Zi Ji, and about 10,000 at Xia Guan ([2], 16 February 1938). He was sure many husbands and sons would never return.

Vautrin also wrote of mass burials, providing further evidence of the Massacre. On 25 February when she went to the University Hospital to participate in a meeting of the Nanking Christian workers, she passed the Anhui burial ground. There she "saw men belonging to the Swastika Society still busy burying unclaimed bodies, wrapped in mattering and placed or dragged into the trenches. The odor was so bad that the men have to wear masks" ([2], 25 February 1938). She found that, 
until the warm spring and summer of 1938, the bodies of thousands of victims remained unburied. Most had been killed in the first days of occupation. On 6 April, she learned of the work relief project of the International Committee. Two-hundred men connected with the Red Swastika Society were burying bodies found in country areas ([2], 6 April 1938). On the afternoon of 15 April, she visited the headquarters of the Swastika Society in Nanking where she got additional information from the workers and recorded it as follows:

From the time they were able to encoffin bodies, i.e., about the middle of January to 14 April, their society had buried 1793 bodies found in the city, and of this number about $80 \%$ were civilians; outside the city during this time they have buried 39,589 men, women, and children and about $2.5 \%$ of this number were civilians. These figures do not include Hsia Gwan [Xia Guan] and Shan Sin Ho [Shang Xin He] which we know were terrible in the loss of life ([2], 15 April 1938).

\subsubsection{Sexual Crimes}

Much of Vautrin's information about mass killing cases came through indirect channels. In contrast, she witnessed the aftermath of Japanese sexual crimes perpetrated against women almost every day during the Massacre period. She remembered that all days seemed alike as she arrived at the Ginling gate at 7:30 a.m., and watched as "a stream of weary wild[-]eyed women were coming in". Their stories were often the same as they "said their night had been one of horror". They testified that "again and again their homes had been visited by soldiers. (Twelve-year[-]old girls up to sixty-year[-]old women raped. Husbands forced to leave bedroom and pregnant wife at point of bayonet)" ([2], 17 December 1937). She documented some of these horrible cases with anguish.

Early on 16 December, she observed that "there probably is no crime that has not been committed in this city today" ([2], 16 December 1937). She witnessed Japanese soldiers seizing girls passing the Ginling gate. "Tonight a truck passed, in which there were 8 or 10 girls, and as it passed, they called out 'Giu ming' 'Giu ming' [jiu ming]—save our lives" ([2], 16 December 1937). She also recorded that "thirty girls were taken from Language School last night, and today I have heard scores of heartbreaking stories of girls who were taken from their homes last night-one of the girls was but 12 years old...The occasional shots that we hear out on the hills, or on the street, make us realize the sad fate of some man - very probably not a soldier" ([2], 16 December 1937).

On 17 December at 4 p.m. to 6 p.m., Vautrin took in two large groups of women and children. She reported that "weary women and frightened girls [arrived] as a stream, trudging with children and bedding and small packages of clothes" ([2], 17 December 1937). After supper, one of the boys reported to Vautrin and said that many soldiers were on campus and were going through dormitories. Vautrin went with Mr. Li and found two soldiers in front of the Central Building pulling on the door. One said, "Soldiers here. Enemy of Japan" ([2], 17 December 1937). Vautrin said, "No Chinese soldiers." Mr. Li repeated it. One soldier then slapped Vautrin on her face and slapped Mr. Li very severely, and insisted that they open the door. Vautrin pointed to the side door and took them in. They went through upstairs and downstairs looking for Chinese soldiers. When they exited the building, Vautrin saw two additional soldiers had exited the building leading three servants bound together. The soldiers said, "Chinese soldiers", but Vautrin said, "No soldiers. Coolie, gardener." None of the three were soldiers. Vautrin followed the Japanese soldiers to the front door. There, she found a large group of Chinese including her staff, kneeling there beside the road. Later, Rev. Wilson Plumer Mills, Dr. Lewis Smythe, and Mr. George Fitch arrived in Ginling. When they got to the front gate, they were held up by a patrol of Japanese soldiers under the command of a pugnacious and impudent lieutenant. He lined these men up on one side and Ms. Vautrin, Mrs. Tsen, and Mrs. Twinem on the 
other side $[9]^{12}$. After discussion with his soldiers, several times he ordered all foreign men to leave. Vautrin and the Ginling staff dared not move for fear of being shot. They remained still until a quarter to eleven. Later, they learned that while this was going on, all other Japanese soldiers had climbed over the wall and selected 12 women and took them out at side gates, and had seized two additional women from the East Court. She sadly wrote that "Never shall I forget that scene- the people kneeling at [the] side of [the] road, Mary, Mrs. Tsen and I standing, the dried leaves rattling, the moaning of the wind, the cry of women being led out" ([2], 17 December 1937).

During the morning of December 19, after another night of sexual rampage, many women and girls kneeled in terror and urgently begged to be admitted. Vautrin opened the gate but mentioned, "we do not know where they will sleep tonight" ([2], 19 December 1937). Later that day, Vautrin traveled from one end of the campus to the other trying to remove groups of Japanese soldiers from the refugee camp. She went up to South Hill three times, then to the back campus, and then to the old Faculty House where she was told two soldiers had just gone upstairs. "There in room 538, I found one standing at the door, and one inside already raping a poor girl. My letter from the [Japanese] Embassy and my presence sent them running out in a hurry" ([2], 19 December 1937).

On the day before Christmas, Vautrin painfully experienced another shocking tragedy. Japanese troops came to inform her they there "legally" to select and pick up Chinese prostitutes in the Ginling women refugee camp:

About ten o'clock I was called to my office to interview the high military advisor for the-division. Fortunately[,] he had an interpreter with him, an old Chinese interpreter for the Embassy. The request was that they [are] allowed to pick out prostitute women from our ten thousand refugees. They said they wanted one hundred. They feel if they can start a regular[ly] licensed place for the soldiers, then they will not molest innocent and decent women. After promising they would not take any of the latter, we permitted them to begin their search, the adviser sitting in my office during the search. After a long time[,] they finally secured twenty-one, but group after group of girls have asked me if they will select the other seventy-nine from among the decent girls-and all I can answer is that they will not do so if it is in my power to prevent it ([2], 24 December 1937).

The New Year's Day of 1938 did not mean a new beginning for the camp refugees. In the afternoon, Vautrin took her turn staying in the office. At about 3 p.m., one servant came in hurriedly and reported a soldier was taking off with one refugee girl from the camp. "I went out hastily and caught him with her in the bamboo grove just north of the library. He beat a hasty retreat when he heard my voice. Later I sent off two more soldiers who had come on campus at [the] same time" ([2], 1 January 1938). On the same day, she recorded that "A great fire is burning over toward Belimen chiao [Bei Men Qiao] tonight-looting continues...a few days ago twenty[-]seven women were raped on B.T.T.S [Bible Teachers Training School for Women] compound" ([2], 1 January 1938) ${ }^{13}$.

On 28 January, a Japanese officer showed up at the meeting of district heads in the Safety Zone. The meeting was held at the headquarters of the Autonomous Committee ( $\mathrm{Zi}$ zhi wei yuan hui), the puppet government established by the Japanese on 1 January. The meeting announced that all refugees in the Safety Zone must go back to their homes by 4 February. Later, some women returned to their homes but again many of them were robbed, raped, and killed. On 1 February, a 39-year-old woman, whose husband was taken by Japanese soldiers on 27 December and had not returned, arrived to ask Vautrin's permission for her to stay at Ginling. She related her troubled story. During that

12 Letter from Dr. Robert O. Wilson to Family (15 December 1937-9 January 1938), in Record Group 11, Box 229, Folder 3875, College Files: University of Nanking: Correspondence: Wilson, Robert 1937, Yale University Divinity School Library. Dr. Wilson's letter of diary on December 18 recorded that, "Today marks the sixth day of the modern Dante's Inferno, written in huge letters with blood and rape. Murder by wholesale and rape by the thousands of cases." See The Nanking Massacre Archival Project, NMP 0016 (cited in [9]).

13 Here, Vautrin made a typographical mistake in her diary that "Belimen" should be "Bei Men". 
morning, she had persuaded a man who worked with her in the same family to accompany her and go back to the home to get belongings that might remain there. The woman was seized and raped by five Japanese soldiers, and the man was slapped and robbed of nine dollars. Just after that woman left Vautrin's office, another 57-year-old came in. She and her husband had returned to their home on Sunday, but her husband had been forced to get out of their home and two soldiers had raped her. Vautrin mentioned that these "Women do not willingly tell me these tales for they feel the disgrace of it too deeply. How can young girls be asked to go home? Again today, every time I went across the campus a group would gather and implore me to make it possible for them to stay. How my heart aches for them!" ([2], 1 February 1938).

Vautrin's heartache for refugee women and girls never did cease. On 15 March at 11:30 a.m., she went with Rev. John G. Magee, then the chairman of the International Red Cross Committee of Nanking, to the south of the city to take pictures related to another one of these tragedies. She learned that a 48-year-old woman had been raped 18 or 19 times and her 76-year-old mother twice. Vautrin commented that "the story is vastly beyond heartless belief" ([2], 15 March 1938). In the sight, most of the south gate streets were still very much deserted, and among the people, there were only a few old women.

\subsection{Operating Programs in Rehabilitation and Christian Education}

The non-profit and purely philanthropic International Committee for the Nanking Safety Zone was organized on 22 November 1937. Its members had been composed entirely of international neutrals with a core body of missionaries. In the practice of relief, it worked in cooperation with other institutes serving in the city, including the Nanking International Red Cross, the University Hospital, the Christian schools, and churches, etc. At first, the work for the refugees was carried out by three commissions: Food, Housing, and Sanitation, and later the Rehabilitation Commission was added. According to historian Miner Searle Bates who worked as a Disciples of Christ missionary professor in Nanking, very nearly 250,000 people were packed into the Safety Zone in the last desperate rush after the fall of the city on 13 December [9] ${ }^{14}$. Of those refugees, approximately 70,750 were located in 25 large concentration centers or camps for the second half of December and 62,500 throughout January. Six camps in service for the period of December to February had been closed by early March. Thirteen more were closed in March and April. Through to 21 May 1938, only six carried for 7083 people ([2], 24 May 1938).

The Ginling College was one of those last six camps. It maintained a camp for refugee women and their children, numbering some 10,000 during the worst days of December, declining gradually in January, and remaining at around 3000 to the end of March ([2], 16 March 1938) ${ }^{15}$ and around 900 to the end of May ([2], 29 May 1938) ${ }^{16}$. The history of the camp was closely connected with issues of security and poverty. No barrier had been found in race, nationality or religious beliefs among the members of the College Emergency Committee and staff or volunteers who desired to aid the poor in their time of need. During the terror and destruction of the Nanking Massacre and the period of later relief, Minnie Vautrin and her team deployed several rehabilitative and Christian educational programs. Additionally, she played a leading role in the refugee camp daily life.

14 The numbers of this paragraph and of this note, except from reference [2], can be found all from the source "Report of the Nanking International Relief Committee (November 1937-April 30, 1938)", in Miner Searle Bates Paper, The Nanking Massacre Archival Project, NMP 0248. The numbers of refugees in the Safety Zone were: February for 36,800, March for 26,700, and April for 21,750.

15 According to Vautrin's Diary on 16 March, there were 3310 refugees in the following six buildings (with number following the name of the building) at Ginling campus: Central 528, Science 517, Arts 885, Dormitory Northeast 487, Dormitory Northwest 431, and Dormitory Southwest 497.

16 Before 8 a.m. on 29 May, Mr. Chen checked on the Ginling camp population which stood at only 923 in six buildings (with number following the name of the building): Central 212, Science 115, Recitation Hall 260, (Northeast) 700 Dormitory 119, (Northwest) 600 Dormitory 78, (Southeast or Faculty House) 500 Dormitory 139. I used the Ginling College 1937 map from source [3] (no page number) drawn by Suping Lu to indicate the names of buildings in this note. 


\subsubsection{Food and Medical Protection}

Based on medical advice, the International Committee made an effort to introduce necessary food elements within the refugees' diet. It provided Chinese broad bean (can dou) as the exclusive food of the poorest people to be added to the rice gruel. Vautrin requested broad beans for the Ginling camp women and children, as they were among the poorest and needed basic nutrition. On 11 April, Mr. Chen finally finished reorganizing the kitchen and added the beans to the diet ([2], 11 April 1938).

Partly supported by the Red Cross funds, a squad from the University Hospital was given facilities and assistance in generating a preventive campaign among the refugee camps. At the same time, they distributed large supplies of cod liver oil among the children of the camps. The University Hospital acted as an agent of the International Committee. From March 1938, the Committee maintained a supply of powdered milk for use among refugee babies. Mrs. Tsen and her three helpers were giving milk to 34 babies and cod liver oil to 240 under 12 in Ginling camp ([2], 10 March 1938). Vautrin also kept close ties with the University Hospital, the University of Nanking, and other Christian institutes. Up to 10 March, Dr. Richard Freeman Brady had vaccinated more than 7582 persons in the Safety Zone camps since his arrival on 21 February. About 2000 of those vaccinated were located at Ginling ([2], 10 March 1938). From 26 to 29 April Dr. Lee and several assistants and nurses arrived in the Safety Zone to provide inoculations against typhoid and cholera. During those four days, they inoculated 1201 Ginling refugees ([2], 10 March 1938) ${ }^{17}$. Mrs. Tsen had organized it very well without a murmur.

\subsubsection{Cash Relief, Work Relief, and Small Investment}

During the spring and summer of 1938, Vautrin and her team continued their efforts in cash relief, work relief, and providing small investments for productive businesses. Cash relief gave some help to the people of the bottom class and aided their return home and their independent work outside the refugee Safety Zone. Through her close working relationships with the core members of other Christian relief bodies, Vautrin applied "special grants" to cover costs of the Ginling refugee camp for continuing its usual work and providing special aids. For instance, the Ginling camp and school received more than $\$ 1600$ in subsidies from the International Committee to maintain a provision for some 600 young refugee women through the summer of $1938[9]^{18}$. To provide partial support for five blind girls left helpless in Ginling, the International Committee paid over $\$ 500$ to enable their entry into an excellent school in Shanghai for the blind.

Vautrin and Mrs. Tsen also applied work relief to provide support for those in most need in the Ginling camp. Using a small allowance from the International Committee, they paid salaries to extra assistants and servants in the divisions of business, supervision, education, and health. These staff had been mainly from the "invited" refugees such as Ms. Rachel Wang, Mr. Wang, Mr. Djao, and Mr. Swen. In April, Mrs. Tsen and her assistants organized the poorest 100 women in camp for sewing of civilian clothes and 19 for weeding, all to be provided with small payments ([2], 5 and 11 April 1938).

A group of American women interested in helping children in China sent the Ginling camp, through a friend in China, a sum of fifty dollars Chinese currency. After an investigation, Vautrin and her colleagues decided to choose ten women with the most pressing needs. Three stories of these "start-up" investments were as follows ([2], 8 June 1938):

Case 1: Woman Li was 60 years old. Her husband Chen was 62. On 16 December, their three sons were taken by the Japanese army and nothing had been heard. Li's eldest son was 35, a seller of fish. He left his wife and four children. Li's second son was 29, a dumpling maker. He left a wife who was expecting a little child very soon. Li's third son was 17 and unmarried. He had

17 The amount of inoculated people in four days from 26-29 April 1938 was respectively 363, 314, 214, and 310.

18 Including the numbers of the next sentence, see "Report of the Nanking International Relief Committee (November 1937-April 30, 1938)", in Miner Searle Bates Paper, The Nanking Massacre Archival Project, NMP 0248. 
been selling papers to make a living. Li was given $\$ 6.00$ to start a small business for selling doughnuts for Chinese breakfasts.

Case 2: Li Yung-shi was 35 years old. Her husband was an umbrella maker and had been taken by Japanese on 15 December and disappeared. She and her two little girls aged 14 and 5 were living at the home of some neighbors who felt sorry for her. Li's home was burned by the Chinese army for military purposes related to defense and she had nothing left. Even her bedding had been taken by Japanese soldiers when they seized the city. She was given $\$ 6.00$ to begin a small business selling candles, fans, soap, etc.

Case 3: Wang Siu-shing was 21 years old. Her mother died in the autumn of 1937 during the air raids. On 16 December, her father, age 43, her uncle, age 31, and a younger brother of 19 were all taken by the Japanese soldiers. Left with three younger brothers, one of 16 with mental problems and the others only 13 and 6 , Wang received $\$ 5.00$ to start a business. They had returned to the home of one friend of her parents, but that family was also very poor and could not help.

\subsubsection{Mental Relief and Bible Classes}

The unrelenting Japanese air raids began 15 August 1937, followed by the Massacre on 13 December and in the following six weeks. These events and the aftermath of the invasion created an increasing hunger for the kind of solace often found in religion. When refugee women, men, and children went forward "to meet a group of fierce soldiers whose shining bayonets were marked with fresh stains of blood", the desire for genuine spirituality grew within the Ginling community [11]. During those miserable days, except in the summit period of the refugee load, Minnie Vautrin and her colleagues arranged worship services for refugees on Wednesday and Sunday evenings. They had loved to sing songs, "O, save my country, Lord" and "We love our native land". Early in August 1937, Wu Yi-fang, Vautrin, and their staff team started prayer meetings on Wednesday and Saturday mornings. In January 1938, those meetings met daily except Sunday, the time for church worship services. "Words cannot express the value these meetings have been in strengthening and binding us together and giving us [the] power to meet the difficult problems of each day. How real and vital prayer has become" [11]. According to Vautrin's report, 12 staff members attended the group prayer meetings as late as the end of January 1938.

On 28 February, Vautrin and her team started a mental rehabilitation project, including classes and preaching services on the theme "The Life of Christ". About 500 women attended ten classes divided by their reading skills and ages ([3], p. 181). On 2 March, another six classes started according to students' literate ability and ages. Among them, some were children and others adults. Later, for about 500 young women who could not read or write, Vautrin developed seven sessions to teach them the Gospels [12]. Ms. Rachel Wang, a student of the Nanking Theological Seminary, directed this project with assistance from Ms. Hsueh and Ms. Lo, the day school teachers, and Yang Ih-tsing and $\mathrm{Wu}$ Ai-djen, two Presbyterian refugee volunteers. Every class met three to five times weekly in the morning. All refugee students learned selected Psalms and passages from the Bible, for which Ms. Wang had selected the 23rd and 121st Psalms, the Beatitudes, and the Lord's Prayer. The refugee students also learned hymns. Favorite songs included "What a Friend We Have in Jesus" and "Jesus Lover of My Soul". For an Easter hymn, they learned "The Day of Resurrection". Teachers selected passages and hymns to deliver messages of healing. Except for Vautrin and Ms. Hsueh, the day school teachers were all refugees themselves. The six-week project on "The Life of Christ" ended on around Easter Monday, April 4. Two performances of the Easter Pageant attracted 650 to 700 people on 16 April and 900 to 1000 on 17 April ([2], 16-17 April 1938). The International Relief Committee members, Dr. Lewis Smythe, Rev. John Magee, and Rev. Wilson Mills, attended with their refugees. On 18 April, each of the 23 classes of the project performed their own programs.

With the help of pastors from the American Church Mission, Vautrin and the Ginling team resumed the regular Sunday and Thursday afternoon preaching services held by Ms. Lo at the end of 
January. Each afternoon at two o'clock, young woman refugees, with at least an age of 15, gathered together in the South Studio or the big chapel, to listen to sermons and pray for concerns. About 150 to 400 people, usually the largest on Sundays, attended the service while Vautrin and other staff took turns leading the group in singing [12]. These meetings also focused on the theme "The Life of Christ" and answered the question "what it means to be a refugee". The topics of preaching had been carefully selected by five men who came to Ginling from the Episcopal Church, the only church that had kept its workers together. Rev. John Magee and Rev. Ernest Forster rented three houses in the Safety Zone and stayed with other clergies and some church members and families. One of the five clergies spoke in turn at each of these meetings. The Presbyterian and Disciples missions had no ordained clergy in Nanking:

There have been five members of my [Disciples of Christ] mission in the 14 missionaries in Nanking, and wish [there] were more, for all five of us are tied up in institutions and do not have time to give to our churches. I cannot tell you how great that opportunity is now-a great open door within which we could do untold service through sympathy, understanding, and helpfulness. If all our evangelistic men and women were here, they could not meet this need ([3], p. 180) ${ }^{19}$.

At the same time as the afternoon sessions for women, the camp hosted a children's meeting in the Science Lecture Hall. The day school teachers conducted these meetings. Vautrin got the teaching materials from Shanghai. The most advanced class and children's Bible class programs culminated in special performances during the Holy Week.

\subsection{Petition for Civilian Men}

Early in January, Vautrin became conscious that many refugee women at Ginling were left with small children and one or two old people. Many had lost the only source of family income because their husbands or sons had been taken by Japanese soldiers soon after the fall of the city on 13 December and never returned. These women felt a future of begging might be their only option. They asked Vautrin to investigate whether any of their men survived and could be returned. Vautrin and her assistants investigated some cases and made sure that these men were civilians. Between 24 January and 8 February, they discovered some 738 cases of civilian men taken by Japanese soldiers on 16 December [12]. Vautrin went to the Japanese Embassy on 9 February and submitted the case reports to two Japanese officers, but they did nothing.

Later, Vautrin learned that a large group of male civilians had been imprisoned as laborers in pitiful condition at the Model Prison (Mo Fan jian yu) near the National Central University. Some women had found their husbands and sons at the prison. Again, Vautrin and her assistants went into action. They asked the refugee women to sign a petition and handed it to the Japanese authority and the local government. As a result, between 18 and 24 March, a total of 1245 women came in and signed the petition [12]. Unfortunately, most of them were very poor farmers, gardeners, coolies, and merchants without education. They could only make a fingerprint underneath their names following the guidance of camp staff. This petition made a significant difference. The Japanese authority asked for supplemental information several times through Dr. Xu Chuanyin, and finally, 30 men were released on 3 June from the Model Prison ([2], 3 June 1938). On 10 June, a youth from the

19 Letter from Minnie Vautrin to Mrs. Thurston on 9 March 1938. Record Group 11, Box 145, Folder 2875, Special Collections, Yale University Divinity School Library. The five members of the United Christian Missionary Society (Disciples of Christ) were Miner Searle Bates (Administrator and Professor of History at the University of Nanking), Grace Louise Bauer (Medical Lab Technician at the University Hospital), James Henry McCallum (Administrator of University Hospital), Lewis Strong Casey Smythe (Secretary of the International Committee and Professor of Sociology at the University of Nanking), and Minnie Vautrin (Administrator and Professor of Education at Ginling College). This list is compiled with data from the Nanking Massacre Archival Project and cross-referenced with the research from two source books ([8], pp. xviii-xxvii; [10], pp. 11-18). 
released men arrived at Ginling and thanked Vautrin. He told her that 3000 men in the prison earlier had been transferred to Shanghai ([2], 10 June 1938). Vautrin did not report any additional information related to these men.

\section{Conclusions}

For Chinese refugee women and children at the Ginling campus, Vautrin and her team's protection served as a harbor of safety in the midst of a crisis occasioned by war. On 1 May, a woman who attended the Sunday afternoon worship at Ginling told Ms. Lo that her mother, a devout Buddhist, "having been a vegetarian from the time she was left a widow at the age of 19" to that afternoon when she was more than 80, "kowtowed ten times each day" for Hua Qun (Vautrin's Chinese name), Hua xiao jie (Ms. Hua), hoping that she would be able to continue her work at the camp to provide shelter for all the young women ([2], 1 May 1938).

The stress of these months during 1937 and 1938 took a heavy toll on Minnie Vautrin's emotional and psychological health. The following short passages are taken from her diary illustrating this woman missionary's personal struggles to process the events occurring during these months:

The Japanese are said to be very near Gwang Hwa Gate [Guang Hua Men]. Fires have been seen around the city a good part of [the] day, and tonight the sky to the west is aflame-the destruction of the houses of the poor just outside city wall. John Magee says his compound looks like an island in a sea of smoldering ruins...when the city is turned over. Who will take care of them during coming months? ([2], 10 December 1937).

Tonight Nanking has no lights, no water, no telephone, no telegraph, no city paper, no radio. We are indeed separated from all of you by an impenetrable zone ([2], 13 December 1937).

Tonight I asked George Fitch how the day went and what progress they had made. And his reply was, "It was hell today. The blackest day of my life." Certainly[,] it was the same for me...Oh, God, control the cruel beastliness of the soldiers in Nanking tonight, comfort the heartbroken mothers and fathers whose innocent sons have been shot today, and guard the young women and girls through the agonizing hours of this night. Speed the day when wars shall be no more ([2], 16 December 1937).

It seems in several homes near West Flower Gate [Xi Hua Men], the soldiers failing to find young girls are using teenage boys ([2], 7 February 1938) ${ }^{20}$.

I shall never bring pressure on women to leave again. My experience on that was too bitter. One married woman of 27 whom we urged to go back to her husband about December 20 was raped by three soldiers within three hours after she left us; a woman of 48 was raped by six men the night she left us. I learned my lesson and will not easily forget it ([2], 4 April 1938).

The terrible Ginling images and the Nanking nightmare of those dark days and fearful nights haunted Vautrin repeatedly and eventually resulted in a complete mental and emotional breakdown by the middle of April 1940. On 14 May, authorities escorted her out of Nanking to America for medical treatment. On 8 June, Doctor Woods in the Psychopathic Hospital of the State University of Iowa diagnosed her case as Involuntary Depression, what today many would identify as Post Traumatic Stress Syndrome (PTSD) ([13], pp. 23-32). She experienced moments where she seemed on the cusp of recovery but always fell back into severe depression. On 14 May 1941, Vautrin committed suicide by opening the gas jets of the kitchen stove in her apartment in Indianapolis, Indiana, leaving a note:

20 The West Flower Gate was the western gate of the Ming Forbidden City. The city was burned and destroyed in the early 1860s during the Taiping Heavenly Rebellion. In the 1930s, only relics of the gate remained. Vautrin refers to the neighborhood near the former gate. 


\section{Dear Friends:}

This process of mental deterioration has evidently been going on for years without my realizing it. I prefer death to insanity. To all who have been so loving, so patient and so generous I am deeply grateful. To my family in Michigan[,] I cannot express my remorse and sorrow. I should have meant so much to them but I have meant so little in their lives. This failure has been unconscious on my part-not intentional. I cannot forgive myself-so I do not ask you to forgive.

I know many of you think I am better-but as a matter of fact[,] my mind is fast reaching a state beyond my control.

I have deeply loved and respected the cause of missions and Ginling College. Had I ten perfect lives I would dedicate them all to this cause of Kingdom building - but alas! I have failed and injured the cause with the one life which has been mine. My remorse and regret are deep and genuine.

May those of you who have dedicated your strength to this great work, be given the vision and strength and courage to go forward—and to be faithful to the end.

Sincerely yours,

(signed) Minnie Vautrin ([10], pp. 165-66) $)^{21}$

The "Goddess of Mercy" memorialized by the Chinese forever unexpectedly took her own life. Her heroic courage, her insistent determination to protect Chinese refugee women and children during the Rape of Nanking and its accompanying crisis during the war will long be remembered. However, a new generation of readers should "bear in mind that the other side of celebration was anguish: several of the Westerners most active in the rescue effort suffered breakdowns after leaving China" ([14], p. 12). Minnie Vautrin was only one of them.

Acknowledgments: The author would like to thank Mark G. Toulouse for his significant intellectual guidance and support for this paper. He would also like to thank several scholars for their comments (Xiaohong Zhu, Thomas In-sing Leung, Daniel Hee Nam Yeung, Joseph Kaung, Fuk Tsang Ying, Chloe Starr, Wenh-In Ng, Swee Hong Lim, Jiadong Zheng, and Ying Gao) during the Christianity and China in the 21st Century international conference hosted by Emmanuel College, University of Toronto, on 22-24 October 2015.

Conflicts of Interest: The author declares no conflict of interest.

\section{Glossary}

\begin{tabular}{ll}
\hline Allison, John Moore & 阿利森/爱利生 \\
\hline Bates, Miner Searle & 贝德士/贝茨/裴志/裴滋 \\
\hline Bauer, Grace & 鲍尔 \\
\hline Bei Men Qiao (Beimen chiao) & 北门桥 \\
\hline Bible Teachers Training School for Women & 金陵女子神学院 \\
\hline Cai Yu xun zhang & 采玉扐章 \\
\hline can dou & 蚕豆 \\
\hline Durdin, Frank Tillman & 杜丁/德丁 \\
\hline Espy, James & 埃斯皮 \\
\hline Fitch, George Ashmore & 费吴生/费奇/菲奇 \\
\hline
\end{tabular}

21 Minnie Vautrin, “Last Message”, 14 May 1941, correspondence, Disciples of Christ Historical Society Library, Nashville, Tennessee (cited in [10]). 


\begin{tabular}{|c|c|}
\hline Forster, Ernest Herman & 福斯特/福斯多/厄内斯特 \\
\hline Gale, F. C. & 盖尔 \\
\hline Gin Ling Yong Sheng & 金陵永生 \\
\hline Ginling College & 金陵女子文理学院/金陵女子大学/金女大 \\
\hline Gu Lou yi yuan (University of Nanking Hospital) & 鼓楼医院 \\
\hline Guan Yin pu sa (Guanyin Buddha/Goddess of Mercy) & 观音菩萨 \\
\hline Guang Hua Men (Gwang Hwa Gate) & 光华门 \\
\hline Hu Ju Guan (Hu Gi Gwan) & 虎踞关 \\
\hline Huo pu sa (Living Buddha/Goddess of Mercy) & 活菩萨 \\
\hline Hynds, Iva & 海因兹 \\
\hline Jacquinot Safe Zone (Rao Jiaju/Shanghai/Nanshi an quan qu) & 饶家驹/上海/南市安全区 \\
\hline Jinling da xue (University of Nanking) & 金陵大学 \\
\hline jiu ming (giu ming) & 救命 \\
\hline Kearney, James & 肯尼/基尔尼 \\
\hline Magee, John Gillespie & 马吉/梅奇/马约翰 \\
\hline McCallum, James Henry & 麦卡伦/麦考伦/麦卡勒姆 \\
\hline McDaniel, Charles Yates & 麦克丹尼尔 \\
\hline Menken, Arthur von Briesen & 门肯 \\
\hline Mills, Wilson Plumer & 米尔士/米尔斯/密尔士 \\
\hline Mo Fan jian yu (Model Prison) & 模范监狱 \\
\hline Nanjing da tu sha (Nanking Massacre/Nanking Atrocity/Rape of Nanking) & 南京大屠杀 \\
\hline Nanjing guo ji an quan qu (Nanking International Safety Zone) & 南京国际安全区 \\
\hline Nanking Theological Seminary & 金陵神学院 \\
\hline Pickering, J. V. & 毕戈林/皮克林 \\
\hline Rabe, John D. & 拉贝/拉比/锐比/艾拉培 \\
\hline Riggs, Charles Henry & 林查理/里格斯/李格斯 \\
\hline San Cha He (San Chia-ho) & 三岔河 \\
\hline Shang Xin He (Shan Sin Ho) & 上新河 \\
\hline Smith, Leslie C. & 史密斯 \\
\hline Smythe, Lewis Strong Casey & 史迈士/斯迈思 \\
\hline Sone, Hubert Lafayette & 宋煦伯/宋尼/索恩 \\
\hline Sperling, Eduard & 施佩林/史波林 \\
\hline Steele, Archibald Trojan & 斯提尔/斯蒂尔 \\
\hline Steward, Albert N. & 史德蔚/司徒华/司徒尔特 \\
\hline Thurston, Matilda Calder & 德本康夫人 \\
\hline Timperley, Harold John & 田伯烈/丁伯莱 \\
\hline Trautmann, Oskar Paul & 陶德曼/特劳特曼 \\
\hline Trimmer, Clifford Sharp & 特里默/德利谟/崔默 \\
\hline Tsen, Shui-fang/Mrs. Tsen (Cheng, Ruifang) & 程瑞芳/程夫人 \\
\hline Twinem, Mrs. Paul de Witt (Mary D. Fine) & 戴籁三夫人/特文兰太太/德威南太太 \\
\hline Vautrin, Minnie/Wilhelmina (Hua Qun/Ms. Hua/Hua xiao jie) & 魏特琳/沃特林/华群/华小姐 \\
\hline Wilson, Robert Ory & 威尔逊 \\
\hline $\mathrm{Wu}$, Yi-fang & 吴贻芳 \\
\hline Xi Hua Men (West Flower Gate) & 西花门 \\
\hline Xia Guan (Hsia Gwan) & 下关 \\
\hline Xu, Chuanyin (Hsu, C. Y.) & 许传音 \\
\hline Yan Zi Ji (Yen Dz Gi) & 燕子矶 \\
\hline $\begin{array}{l}\text { Zi zhi wei yuan hui (Tze Chih Wei Yuen Hwei, Autonomous } \\
\text { Committee/Self-Government Committee) }\end{array}$ & 自治委员会 \\
\hline
\end{tabular}




\section{References}

1. Hua-ling Hu. American Goddess at the Rape of Nanking: The Courage of Minnie Vautrin. Carbondale: South Illinois University Press, 2000.

2. Diary of Wilhelmina [Minnie] Vautrin, 1937-1940 (FILM Ms 62). Directed by Archival Microfilming Services. New Haven: Archival Microfilming Services, 1993. Archives of the United Board for Christian Higher Education in Asia, Record Groups of No. 8 and No. 11, Special Collections, Yale University Divinity School Library.

3. Minnie Vautrin. Terror in Minnie Vautrin's Nanjing: Diaries and Correspondence, 1937-38. Edited by Suping Lu. Urbana: University of Illinois Press, 2008.

4. R. John Pritchard, and Sonia Magbanua Zaide, eds. The Tokyo War Crimes Trial, Vol. XX, Judgment and Annexes. New York: Garland Publishing, 1981.

5. $\quad$ Suping Lu, ed. A Mission under Duress: The Nanjing Massacre and Post-Massacre Social Conditions Documented by American Diplomats. Lanham: University Press of America, 2010.

6. Joshua A. Fogel, ed. The Nanjing Massacre in History and Historiography. Berkeley: University of California Press, 2000.

7. Xingzu Gao. "Zai ‘Qin hua ri jun Nanjing da tu sha guo ji xue shu yan tao hui' shang de jiang hua (A Keynote Speech at the International Conference on Nanking Massacre)." In Qin Hua Ri Jun Nanjing Da Tu Sha Guo Ji Xue Shu Yan Tao Hui Lun Wen Ji (Papers of the International Conference on Nanking Massacre). Edited by Anji Chen. Hefei: Anhui University Publisher, 1998.

8. Kaiyuan Zhang, ed. Eyewitness to Massacre: American Missionaries Bear Witness to Japanese Atrocities in Nanjing. New York: M. E. Sharpe, 2001.

9. "Nanking Massacre Archival Project (NMP)." Yale University Divinity School Library. Available online: http://web.library.yale.edu/divinity/nanking/documents (accessed on 28 May 2016).

10. Suping Lu. They Were in Nanjing: The Nanjing Massacre Witnessed by American and British Nationals. Hong Kong: Hong Kong University Press, 2004.

11. Minnie Vautrin. "A Review of the First Month, December 13, 1937-January 13, 1938." Archives of the United Board for Christian Higher Education in Asia, Record Group No. 11, Box 145, Folder 2875, Special Collections, Yale University Divinity School Library.

12. Minnie Vautrin. "The Second Report: A Review of the Period January 14-March 31, 1938." Archives of the United Board for Christian Higher Education in Asia, Record Group No. 11, Box 145, Folder 2876, Special Collections, Yale University Divinity School Library.

13. Sheng Zhang. "Nanjing da tu sha shou hai zhe PTSD chu bu yan jiu (The PTSD Study of the Victims of the Nanking Massacre)." Kang Ri Zhan Zheng Yan Jiu (The Journal of Studies of China's Resistance War Against Japan) 74 (2009): 23-32.

14. Timothy Brook, ed. Documents on the Rape of Nanking. Ann Arbor: The University of Michigan Press, 1999.

(C) 2016 by the author; licensee MDPI, Basel, Switzerland. This article is an open access article distributed under the terms and conditions of the Creative Commons Attribution (CC-BY) license (http://creativecommons.org/licenses/by/4.0/). 